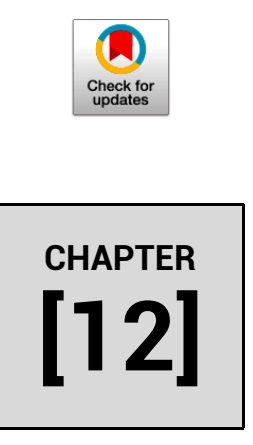

In: Environmental Degradation: Causes and Remediation Strategies

DOI: 10.26832/aesa-2020-edcrs-012

\title{
Solid waste management and its role in mitigating environmental degradation with special reference to recycling of wood wastes
}

Ettammal Sreenivasan

Technical Manager \& Head, R\&D, The Western India Plywoods Ltd, Mill Road, Baliapatam P.O, Kannur, Kerala - 670010, India

ABSTRACT Due to rapid industrialization, urbanization and population growth in India, solid waste generation has been increased to a large extent. In recent years, disposal of solid wastes has caused serious environmental hazards and economic problems. India generates $1.45 \mathrm{MT}$ of wastes per day at present. Annual increase in overall quantity of solid waste is assessed at about $5 \%$ and nearly three-fourths of the waste is generated in urban areas. Municipal Solid Wastes (MSW) amount is expected to increase significantly in the near future as the country strives to attain an industrialized nation status by the year 2020. When solid waste is disposed off on open lands or in low-lying landfill areas, it causes an adverse impact on the environment, such as ground water contamination, generation of inflammable gases, acidity to surrounding soil, release of green house gases, etc. Huge quantity of wood wastes generated through forestry and agricultural practices, paper pulp industries, wood-based industries, and many agro-industries also pose an environmental pollution problem. Sadly, much of the lignocellulose waste is often disposed by biomass burning, which is not restricted to developing countries alone, but is considered a global phenomenon. This chapter discusses the environmental impacts of improper solid waste management, structure and sources of waste generation and regulations and also deals with the details of waste processing techniques with special reference to the low-cost methods of converting wood wastes and residues from plywood and other wood-based units into useful products.

\section{KEYWORDS}

Environmental management, Recycling, Solid waste, Wood waste

Ettammal Sreenivasan, Email: dr.sreeniettammal@gmail.com

(C) 2020 | Agro Environ Media I Agriculture and Environmental Science Academy, Haridwar, India 


\section{Introduction}

Solid wastes are organic and inorganic waste materials produced by various activities of our society, which have lost their value to the first user. This includes household garbage, rubbish, sanitation residues, construction and demolition debris, industrial and biomedical wastes. A society receives raw material and energy as inputs from the environment and gives solid waste as output to the environment. In the long-term perspective, such an input-output imbalance degrades the environment (Ramachandra and Bachamanda, 2007). Due to rapid industrialization, urbanization and the ever-increasing population solid waste generation has been increased to a large extent. In recent years, disposal of solid wastes has caused serious environmental hazards and economic problems. Burning of solid wastes contributes tremendously to environmental pollution thus, leading to polluted air, water and land. Risks to the public health and the environment due to solid waste in large metropolitan areas are becoming intolerable.

India generates $1.45 \mathrm{MT}$ of wastes per day at present and is facing a municipal solid waste dilemma, for which all elements of the society are responsible. The explosion in population is changing the nature of solid waste management from mainly a low priority, localized issue to an internationally pervasive social problem. The community sensitization and public awareness is low. There is no system of segregation of organic, inorganic and recyclable wastes at household level.

The management of solid waste is going through a critical phase, due to the unavailability of suitable facilities to treat and dispose of the larger amount of wastes generated daily in metropolitan cities. In some cities, industrial, residential and commercial areas are mixed and thus all waste gets intermingled. Therefore, it becomes necessary that the local bodies along with State Pollution Control Board (SPCB) work out requisite strategy for organizing proper collection and disposal of solid waste.

\section{Improper solid waste management: Its environmental impacts}

Improper solid waste management causes all types of pollution: air, soil, and water. Indiscriminate dumping of wastes contaminates surface and ground water supplies. In urban areas, solid waste clogs drains, creating stagnant water for insect breeding and floods during rainy seasons. Uncontrolled burning of wastes and improper incineration contributes significantly to urban air pollution. Greenhouse gases are generated from the decomposition of organic wastes in landfills while untreated leachate pollutes surrounding soil and water bodies. These negative environmental impacts are only a result of solid waste disposal; they do not include the substantial environmental degradation resulting from the extraction and processing of materials 
at the beginning of the product life cycle. In fact, as much as 95 percent of an item's environmental impact occurs before it is discarded as Municipal Solid Wastes (MSW) (Rajput et al, 2009).

\section{Government regulations}

Integrated Solid Waste Management (SWM) by applying scientific methods is relatively a new concept in India, although there are reports of attempts by Government of India as early as the 1960s when the Ministry of Food and Agriculture offered soft loans of Urban Local Bodies (ULBs) and also financial support given to state governments for setting up of MSW composting units during the fourth five-year plan (1969-74). These initiatives including a modification of this scheme in 1974 to support the major cities were unsuccessful due to a number of reasons.

However, during the recent past, the management of solid waste has received considerable attention from the Central and State Governments and local (municipal) authorities in India and as a result, we have adequate legal framework in India to address SWM. Government has successfully implemented various rules and awareness programmes to ensure proper disposal of solid wastes:

a) The major initiative taken by the Honourable Supreme Court of India in 1998, which resulted in formation of an expert committee to study the status of SWM in Indian cities. This committee identified the deficiencies/gaps in the existing SWM system in the country and prepared the Interim Report in 1999 on SWM Practices for few cities.

b) As a second initiative, in conformance with Sections 3, 6 and 25 of the Environment Protection Act of 1986, and on the basis on the recommendations by the Committee, the Ministry of Environment and Forests (MoEF) of the Government of India, developed and issued Municipal Solid Waste (Management and Handling) Rules (MoUD, 2000). These rules aim at standardization and enforcement of SWM practices in urban areas. The Manual on Municipal Solid Waste (Management and Handling Rules) 2000 groups SWM activities into six functional elements i.e., a) waste generation, b) waste handling, c) collection, d) sorting, processing and transformation, e) transfer and transport and f) disposal. It also lays emphasis on seeking participation of citizens in waste segregation, prohibiting littering of garbage, proper storage of waste and efficient transportation of waste for its processing and final disposal.

c) RCRA- Nation's primary laws governing disposal of solid and hazardous waste. Passed on Oct 21,1976 and later amended in 1984.

d) The Hazardous Waste (Management and handling Rules) of 1989 is an effective mechanism to regulate the generation, collection, storage, transport, treatment and disposal of hazardous wastes both indigenously generated and imported. 
e) Adopted and notified Bio-medical Waste (Management and Handling Rules) in 1998 with the objective to stop the indiscriminate disposal of hospital waste and ensure that such waste is handled without any adverse effect on human health and environment.

f) Notified in 1999, Recycled Plastics Manufacture and Usage Rules with an amendment in 2003 to ensure proper collection, segregation, transportation and disposal of plastic waste (Rajput et al., 2009).

\section{Industrial wood wastes}

Lignocellulose is the major structural component of woody plants and non-woody plants such as grass and it represents a major source of renewable organic matter. Lignocellulose consists of lignin, hemi-cellulose and cellulose. The chemical properties of the components of lignocellulosics make them a substrate of enormous biotechnological value. Large amounts of lignocellulosic "waste" are generated through forestry and agricultural practices, paper pulp industries, timber industries, and many agro-industries. But, they pose an environmental pollution problem. Sadly, much of the lignocellulose waste is often disposed by biomass burning, which is not restricted to developing countries alone, but is considered a global phenomenon. Wood-based industries in India produce large volumes of residues which must be utilized, marketed or properly disposed of. Heaps of wood residues are common features in wood industries throughout the year. Wood waste is generated in various sectors of the wood industry during processing. This includes wood waste generated from sawmills, furniture industries and plywood industries as they are directly involved with the usage and conversion of timber into its derived products for consumer use. In the sawmill industry, the wood has to be converted into various sizes to maximize profit and also satisfy the demands of the people. Table 1 lists the different types of wood wastes and residues from the various wood processing units. Sawmill and plywood units generate a lot of wood wastes due to the intensity of wood processing. Saw dusts, wood off cuts, wood backs, plain shavings, wood rejects are all wastes generated during wood processing in sawmill.

Table 1. Analysis of residues generated in wood processing units.

\begin{tabular}{ll}
\hline Source & Type of wood wastes and residues \\
\hline Sawmill unit & $\begin{array}{l}\text { Bark, sawdust, trimmings, split wood, planer shavings and } \\
\text { sander dust }\end{array}$ \\
$\begin{array}{l}\text { Block board / Flush door/ Ply- } \\
\text { wood unit }\end{array}$ & $\begin{array}{l}\text { Bark, sawdust, veneer clippings and waste, panel trim, } \\
\text { sander dust and boiler ash }\end{array}$ \\
$\begin{array}{l}\text { Fibreboards units } \\
\text { (Hardboard, Softboard, Pre- }\end{array}$ & $\begin{array}{l}\text { Effluent sludge, Chip wash residue, trimming waste, sander } \\
\text { dust and boiler ash } \\
\text { compressed Board) }\end{array}$ \\
Furniture unit & Sander dust, cutting dust, wood shavings and wood cuts \\
\hline
\end{tabular}


Wastes such as off-cuts, sander dusts, wood shavings and wood chips are produced in the furniture unit. The plywood factory mainly generate wood waste from bark, peeler cores, veneer wastes and panel trims while the quantity of wastes from blockboard and flush door units is very negligible but comes from chip wastes from panel trimmings and dust from sanding machines (Figure 1). Press effluent sludge, chip wash residue and boiler ash are some of the major residues produced in the fibreboard factories.

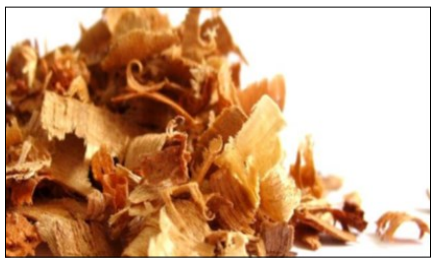

Wood shavings

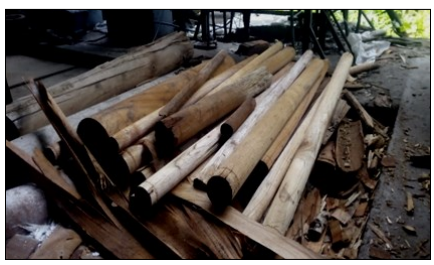

Peeling waste (core)

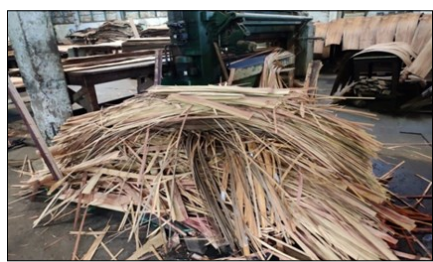

Veneer edging wastes

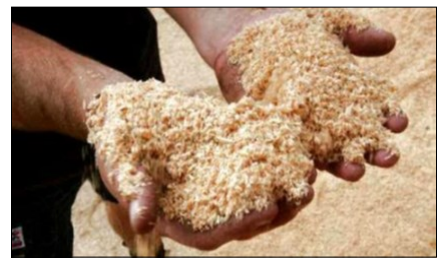

Saw dust

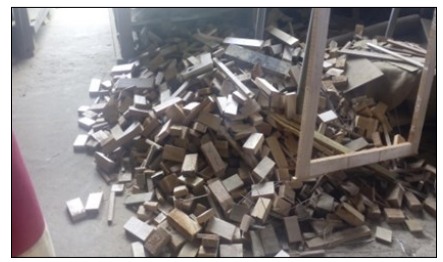

Wood cuts

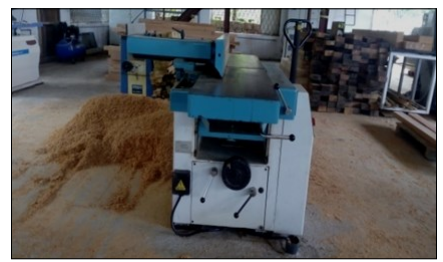

Planer shavings

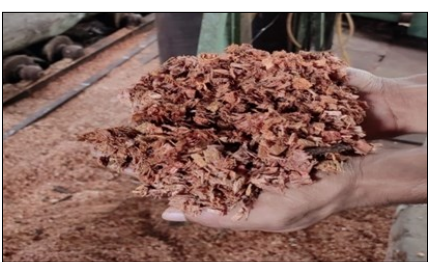

Cross cutting wastes

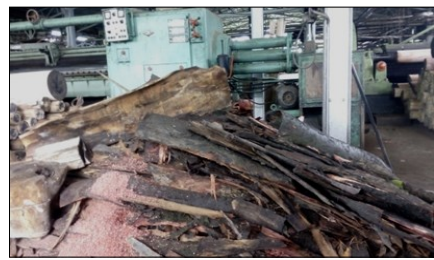

Bark residues

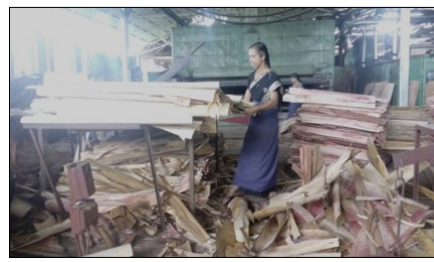

Clipping waste

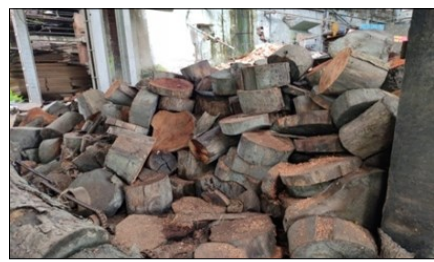

Cross cutting wastes (Timber cuts)

Figure 1. Selected wood wastes from plywood and other wood-based units. 


\section{Wood waste utilization}

Waste generated in wood industries usually become pollutants which pollute the environment either due to burning or improper disposal. Over the years more advanced and improved methods of wood waste utilization have evolved. Saw dusts are used as animal beddings for poultry, in particular board making, as fuel for cooking and as charcoal briquettes. Wood industries utilize waste wood, using it in firing furnaces to raise steam and hot water. Heat generated from this plant can be used domestically and industrially. Bark is sold sometimes to traditional healers or given away free of charge while slabs are disposed by selling them as firewood in local markets. At present, there are a number of methods being used to dispose of solid wastes including the wood wastes and it requires the selection of the correct method focusing on efficient and environmentally safe disposal. New technologies are also being added to assist the organic solid waste treatment, conforming to strict environmental regulations.

\section{Wood waste processing techniques}

\section{Sanitary Land filling}

Sanitary landfill is a solid waste operation that is little better than an open dump. Actually, the term refers to an installation where a satisfactory, nuisance-free waste disposal operation is being carried out in accordance with recognized standard procedures. It is a fully engineered disposal option, which avoids harmful effects of uncontrolled dumping by spreading, compacting and covering the wasteland that has been carefully engineered before use. It also isolates the refuse, minimizing the amount of surface water entering into and gas escaping from the waste, it appears that landfilling would continue to be the most widely adopted practice in India in the coming few years, during which certain improvements will have to be made to ensure the sanitary landfilling (Kansal, 2002).

\section{Incineration}

In incineration, combustible waste is burned at temperatures high enough $\left(900-1000^{\circ} \mathrm{C}\right)$ to consume all combustible material, leaving only ash and non-combustible to dispose off in a landfill. Under ideal conditions, incineration may reduce the volume of waste by $75 \%$ to $95 \%$. In Indian cities, incineration is generally limited to hospital and other biological wastes. This may be due to the high organic material (40-60\%), high moisture content (40-60\%) and low calorific value content $(800-1100 \mathrm{Kcal} / \mathrm{Kg})$ in solid waste. In modern incineration facilities, smokestacks are fitted with special devices to trap pollutants, but the process of pollutant abatement is expensive (Botkin and Keller, 2000). 


\section{Pyrolysis}

Pyrolysis is defined as the thermal decomposition of organic derivatives under inert condition in oxygen-deficient environment. In this process, the chemical constituents and chemical energy of some organic wastes is recovered by destructive distillation. It is a form of incineration that chemically decomposes organic materials at high temperature in the absence of oxygen. Pyrolysis of organic materials produces three phases of matter: a) gaseous products including carbon monoxide and hydrogen (industrially known as syn-gas), methane, short hydrocarbon chain gases, and carbon dioxide, b) small quantities of liquid (known industrially and economically as bio-oil and tars) and c) a solid residue containing carbon and ash (Rajput et al., 2009).

\section{Composting}

Composting is defined as the biological oxidative decomposition of organic constituents in wastes under controlled conditions which allows development of aerobic microorganisms that convert biodegradable organic matter into a final product sufficiently stable for storage and application without adverse environmental effects (Adhikari et al., 2008). It is the process of controlled biological maturity under aerobic conditions, where organic matter of animal or vegetal origin is decomposed to materials with shorter molecular chains, more stable, hygienic, humus rich, and finally beneficial for the agricultural crops and for recycling of soil organic matter.The process is mediated by different microorganisms actuating in aerobic environment: bacteria, fungi, actinomycetes, algae, and protozoa, which participate naturally in the organic biomass or are added artificially (Tuomela et al., 2000). The process can be described by this simple equation:

$$
\text { Organic matter }+\mathrm{O}_{2} \rightarrow \text { Compost }+\mathrm{CO}_{2}+\mathrm{H}_{2} \mathrm{O}+\mathrm{NO}_{3}^{-}+\mathrm{SO}_{4}^{2-}+\text { heat }
$$

Composting method is gaining special consideration these days as an environmentally sound approach to manage organic wastes especially in countries like India, where more than $50 \%$ of solid waste comprises of organic/green waste. Many large-scale compost plants with capacities of ranging from 150 to 300 tonnes / day were set up in the cities of Bangalore, Baroda, Mumbai, Calcutta, Delhi, Jaipur and Kanpur (Sharholy et al., 2008). Now, about 9\% of solid waste is treated by composting (Srivastava et al., 2005; Gupta et al., 2007). Compost, the main product of this transformation is rich in humus and plant nutrients such as nitrogen and phosphorous and the foremost by-products from the process are carbon dioxide, water, ammonia and heat. This potential biological fertilizer would play key role in productivity and sustainability of soil and also protect the environment as eco-friendly and cost effective inputs for the farmers (Oluchukwu et al., 2018) 
a) Composting by effective microorganisms: The technology of EM was originally developed by T. Higa during the1970s at the University of Ryukus, Okinawa, Japan (Higa and Chinen, 1998). EMs have a number of applications including agriculture, livestock, gardening and landscaping, composting, bioremediation, cleaning septic tanks, algal control and household uses. It is a mixture of groups of organisms that has a reviving action on humans, animals and the natural environment and has also been described as a multi-culture of coexisting anaerobic and aerobic beneficial microorganisms. The major microbes contained in EM include: lactic acid bacteria - Lactobacillus plantarum, L. casei, Streptococcus lactis, photosynthetic bacteria - Rhodopseudomonas palustrus, Rhodobacter spaeroides, yeasts Saccharomyces cerevisiae, Candida utilis, actinomycetes - Streptomyces albur, S.griseus and fermenting fungi - Aspergillus oryzae, Mucor hiemalis. They contain various organic acids due to the presence of lactic acid bacteria, which is a strong sterilizing compound and suppresses harmful microorganisms and enhances decomposition of organic matter. Also they have the ability to suppress disease inducing microorganisms such as Fusarium, which occur in continuous cropping programs. The wood wastes, wood residues and other biowastes and the quantity required for the microbial composting process using commercially available EM in dormant state activated by the addition of water and jaggery (pure cane sugar) are shown in Table 2. These residues provided a suitable environment for the effective microorganisms (EM) to grow and multiply and produced a higher quality of compost (Sreenivasan, 2013a). Some of the important observations during this composting period are summarized below: i) The nitrogen content increased during the process of composting and Organic carbon content of the wastes decreased during composting indicating a higher mineralization of organic matter. ii) The C:N ratio of the wastes was higher before composting than after. Enhanced organic matter decomposition in the presence of effective microorganisms results in lowering the C:N ratio. iii) EM controls the foul smell and the process is free of odours. iv) A shift in $\mathrm{pH}$ from the initial condition toward an acidic condition. The occurrence of acidic conditions may be attributed to the bioconversion of the organic material into various intermediate types of organic acid and higher mineralization of the nitrogen and phosphorous into nitrites/nitrates and orthophosphate respectively.

Table 2. Wood wastes and other biowastes used for EM composting.

\begin{tabular}{ll}
\hline Item & Quantity (in $\mathbf{K g})$ \\
\hline Chip wash residue & 450 \\
Press effluent sludge & 200 \\
Saw dust & 250 \\
Boiler ash & 150 \\
Coir pith & 250 \\
Cow dung slurry & 100 \\
\hline
\end{tabular}


b) Vermicomposting: One of the most economically viable processes for the conversion of lignocellulosic wastes into useful products is the use of earthworms. This process by which earthworms are used to convert organic materials (usually wastes) is known as vermicomposting. Vermicomposting is a biotechnological mesophilic process of composting, in which certain species of earthworms such as Eudrilus euginae, Eisenia fetida are used to enhance the waste conversion to produce a better useful end product. Organic wastes can be ingested by earthworms and egested as a peat-like material termed "vermicompost" (Nagavallemma et al., 2004) The goal is to process the material as quickly and efficiently as possible. For vermicomposting different bedding materials are used such as semi-composted solid manure, shredded or mulched paper (non-coloured), cardboard, shredded fall leaves, chopped up straw, sawdust etc. Sawdust is a useful medium mixed with cow dung to produce high quality compost. Large amounts of other lignocellulosic wastes generated through forestry and agricultural practices, paper-pulp industries, timber industries and many agro-industries which generally impose a threat to the environment can be effectively converted to organic manures using this technology. During vermicomposting, the important plant nutrients such as $\mathrm{N}, \mathrm{P}, \mathrm{K}$, and $\mathrm{Ca}$, present in the organic waste are released and converted into forms that are more soluble and available to plants. Vermicompost also contains biologically active substances such as plant growth regulators. With years of research works, WIP has established a pilot scale unit to convert the chip wash residue, a lignocellulosic waste generated in huge quantity from its wood fibre-based hardboard manufacturing plants into vermicompost, using an epigeic earthworm, African Night Crawlers (Eudrilus eugeniae). (Sreenivasan, 2013b) (Figure 2). Investigations to assess the impact of vermicompost produced from this wood waste on growth enhancement and productivity of vegetable crops like tomato, chilli and brinjal grown under field conditions were also carried out in WIP during 2013- 2014( Sreenivasan et al., 2017).
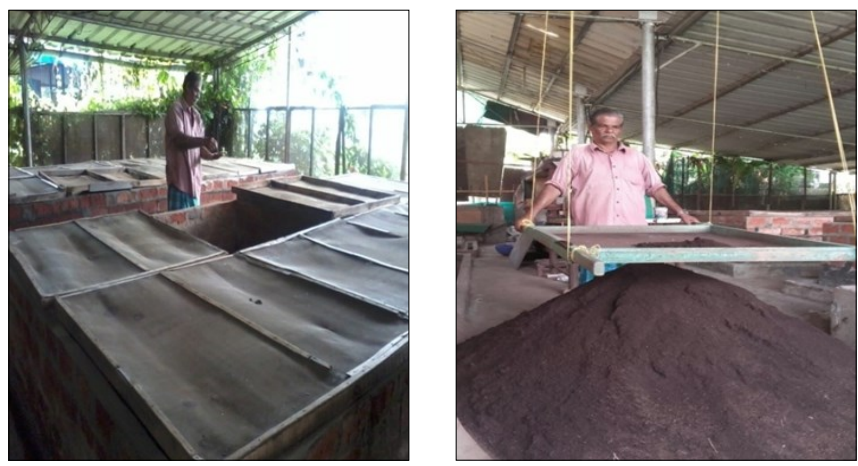

Figure 2. A view of a vermicomposting unit. 


\section{Briquetting}

Biomass from agricultural or forest-based activities and wood-based industries is generally difficult to handle because of its bulky and scattered nature, legal and administrative problems, low thermal efficiency and copious liberation of smoke. In order to achieve maximum and efficient exploitation of waste resources locally available, it is essential to compress them into manageable and compact pieces which have a high thermal value. The process is called briquetting. This process has acquired considerable significance in the recent past, due to its increased fuel efficiency, reduction in bulk, and having high calorific value of the briquettes. Briquettes are made by compacting loose wood waste into a dense material through the application of high temperature $\left(300-350^{\circ} \mathrm{C}\right)$ and moderate pressure. Sawdust, wood chips and bark are suited for making briquetting over which sawdust is the more preferred material. This densification process can produce briquettes with uniform shape and sizes that can be more easily handled using existing handling and storage equipment and thereby reduce cost associated with transportation, handling, and storage (Karunanithy et al., 2012).

Briquetting of sawdust produces renewable environment friendly sources of energy. It is an alternative for cooking fuel. The briquettes are generally burnt as a cleaner and more consistent and alternative to firewood logs, offering a higher energy density and steady combustion. The use of briquettes has considerably reduced the demand for firewood for fuel in industrial boilers. Saw dust briquettes also avoid contaminating environment with lower $\mathrm{SO}_{2}$ (zero percent) and $\mathrm{CO}_{2}$ (15.29 percent) emissions but ash content (1.3 percent) and volatile matter (23.41 percent) is high when compared to fire wood and charcoal. The usage of briquettes as an alternative source of solid fuel for several applications in boilers and industrial use is having increased attention. The briquettes are often used as an energy source for cooking purpose and in some small scale industries like bricks, tea and bakery. Briquetting is also being promoted recently by Government agencies as an excellent method for managing the solid and liquid wastes from plywood factories including the wood wastes and the effluent water from glue spreader washings, preventing these wastes from entering the nearby water bodies and soil.

Biomass briquettes are usually cylindrical-shaped with a diameter between $25-100 \mathrm{~mm}$. and length varies between 100-400 mm. Briquetting of biomass to increase its bulk density consists of applying pressure to a mass of particles with or without a binder and converting it into a compact aggregate.

\section{Techniques for briquetting}

The briquettes are produced by densification of waste biomass using various processes. It has been observed that density, durability and combustion efficiency of briquettes increases with decrease in the size and increase in pressure during preparation. Three versions of compaction/ briquetting machines based on the use of different forms of energy, manually operated, bullock 
operated, and power-operated, have been designed, fabricated and tested by different agencies in the country. The technologies available for the production of direct compaction briquettes are given below:

a) Binderless technology: To compact the biomass, binding materials are not used here and this process involves either the application of high pressure (at the range of $1200-1400 \mathrm{~kg} / \mathrm{cm}^{2}$ ) under which condition the residue gets heated to about $182^{\circ} \mathrm{C}$, and the lignin begins to flow and act as a binder or extracting the diversified material around the room temperature. Here there is no need to add external agent like glue or binder. The existing units are using imported briquetting machines of $400 \mathrm{~kg} / \mathrm{cm}^{2}$ capacity. The manufacture of indigenous briquetting machines has been taken up. These machines are available in the capacity range of 100-3000 $\mathrm{kg} / \mathrm{h}$ operating on electric power.

b) Using binder: The briquetting machines operate at lower pressures $\left(500-1000 \mathrm{~kg} / \mathrm{cm}^{2}\right)$ and are powered by electricity. Briquettes produced by this technology requires binders like molasses, ligno-sulphonates etc. Briquettes produced by this process are suitable neither for household use nor for hotels, canteens, etc. because they release a great deal of smoke while burning. These briquettes however, find use as industrial fuel in boilers in isolated pockets of the country.

A large number of machines (presses) are designed and developed to suit commercial as well as for rural areas in cottage industries.

\section{Briquetting presses}

Briquetting presses are of two types: screw or piston type. In screw type, the biomass is screwed forward under high pressure through a nozzle (funnel shaped) in which case, the briquette gets its cylindrical shape. In the second case, the same forward pressure is effected with a piston. There are two methods to retain their cylindrical form. One of them operates with binding agent and the other without binding agent. Briquetting without binding agent requires a raw material with a maximum moisture content of 15 percent and a briquetting press which can generate a pressure of at least $1000 \mathrm{~kg} / \mathrm{cm}^{2}$. The minimum pressure can vary depending upon the nature of raw material pressed. Briquetting with binding material does not require the same low moisture content which varies depending upon the raw material. The four chief parameters of the briquetting process are: moisture, particle size, binding agent, and level of pressure.

Figure 3 shows one of the two piston presses installed in 2009 and 2011 by The Western India Plywoods Ltd (WIP), Kerala as part of its solid waste management programme to utilize the huge quantity of the wood wastes generated from the manufacturing units and started the production of biomass briquettes with a total capacity of 20 tonnes per day. The briquettes are manufactured by means of one or any combination of the following operations: drying, size reduction, 


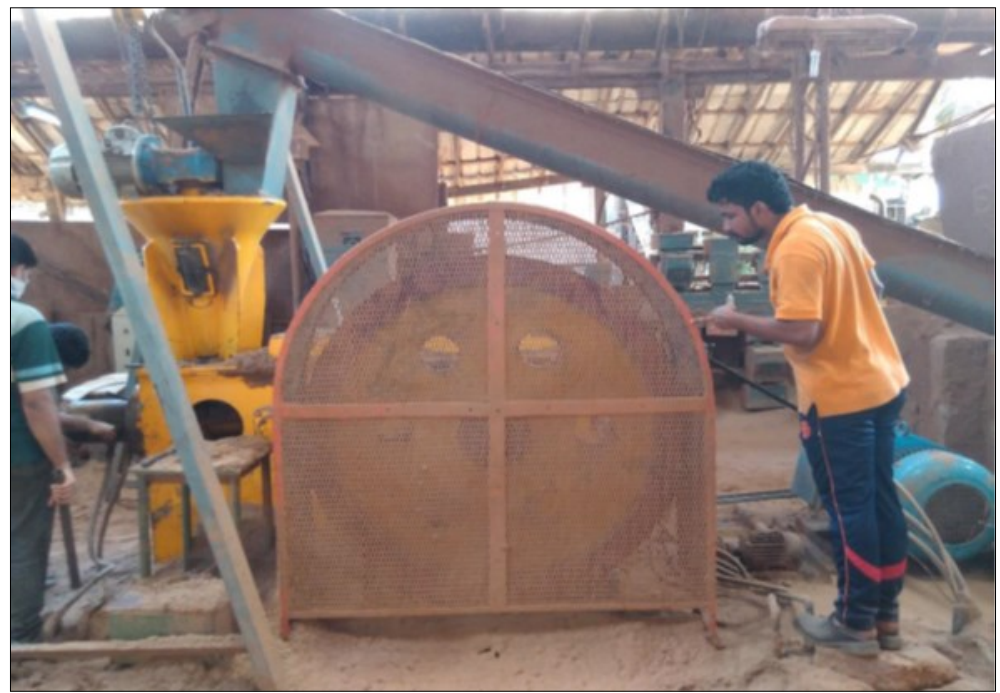

Figure 3. A Biomass briquetting unit.

densification, cooling and dust removal, using a blend of wood wastes obtained from the factories engaged in the manufacturing of a wide range of wood-based panel products like Plywood, Softboard, Hardboard, Densified wood, Pre-compressed press board, etc. This feedstock consists mainly of lignocellulosic wastes like saw dust, wood shavings, peeling waste or bark waste Initially, the product was utilized as boiler fuel for in-house energy requirements. Later due to the increased production, the company started its marketing in Kerala and the neighbouring states. The increasing demand of the product is an indication of its wide acceptability considering its fuel efficiency. The biomass fuel briquettes are obtained with features like: 19.8 percent MJ/kg, 10 percent humidity, 1.3 percent of ashes, 15.29 percent fixed carbon and 83.41 percent of volatile matter. Some of the major features of this product are given in Table 3 .

i) Briquette is a boiler fuel for conversion to energy. It is chosen over coal and other nonrenewable fuel that are hard to obtain and generate.

Table 3. Properties of wood waste fuel briquettes.

\begin{tabular}{lll}
\hline Property & Unit & Result \\
\hline Diameter & $\mathrm{cm}$ & 9 \\
Length, range & $\mathrm{cm}$ & $20-35$ \\
Moisture content & $\%$ & 1.33 \\
Ash content & $\%$ & 2.87 \\
Density, range & $\mathrm{g} / \mathrm{cc}$ & $1.04-1.17$ \\
Weight, range & $\mathrm{kg}$ & $1.30-2.40$ \\
Gross calorific value, range & K.cals/kg & $4200-4600$ \\
\hline
\end{tabular}


ii) They are easy to store, pack and easy to transport and hygienic to handle

iii) Briquettes have consistent quality, high burning efficiency and are ideally sized for complete combustion.

iv) Briquettes have high practical thermal value and low ash content.

\section{Biomethanation}

It is a waste-to-energy process which uses thermo-chemical conversion similar to composting process. It basically taps the methane gas generated from the biochemical reaction in wastes dumped in aerobic digesters (Kumar et al., 2018).

\section{Cement composite bricks}

Development of cement composites mixed with wood wastes and residues to produce low-cost, environmental friendly construction materials, is the latest addition to the list of recycling methods of wood-based industries (Figure 4). In 2017, C. Surabhi and her team investigated the feasibility of producing cement composite bricks using saw dust and boiler ash and focused on the strength and durability of the products (Surabhi et al., 2017)

Manufacturing: Prior to brick formation, particles were soaked in water for 24 hours to reduce the amount of water soluble sugars and tannins and were finally air dried up to 5 percent moisture content for a better combination. Then the materials were mixed appropriately in predetermined ratios and were filled inside a wooden mould of prescribed dimensions for a standard brick size (190 mm X $90 \mathrm{~mm}$ X $90 \mathrm{~mm}$ ). Bricks of sawdust: boiler ash: cement (1:1:1 and 1:1:2) combination was found to be better in strength than the other two samples of composite bricks made of sawdust: cement (1:3 and 1:2) and boiler ash: cement (1:3 and 1:2).

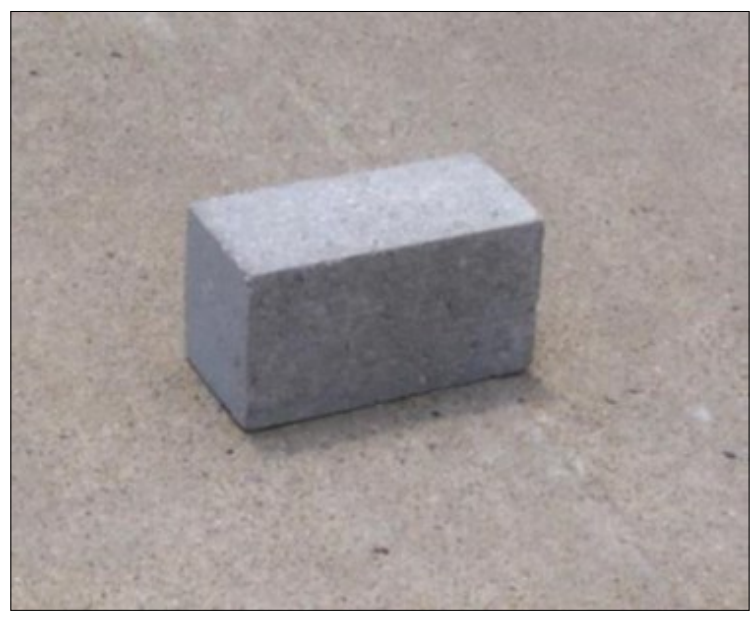

Figure 4. A cement composite brick. 


\section{Future outlook}

Wood wastes are generated daily due to a high demand for engineered wood products for various uses. These wood residues have various consequences on our environment due to improper disposal. The large quantities of wood residues entering the environment can be better utilized to help reduce the impact on our forests and the environment. Unlike small-scale woodbased units, there are well-established integrated wood waste management practices (Figure 5) in large wood-based panel industries like The Western India Plywoods Ltd including the use of bark and peeling wastes as a boiler fuel to generate heat for the facility's process needs.

Wood bark is an important component of hog fuel and is made from wood residues (bark, wood chunks, sawdust, etc.), then processed through a chipper or mill. The end products are coarse chips and clumps which are used as fuel. All other wood wastes from its saw mill, furniture, fibreboard and plywood units are disposed off in a proper manner as detailed above, which in most other cases is either by burning or dumping in open areas which pose environmental hazards. Other wood waste utilization and disposal options under various stages of implementation or consideration by Indian firms include:

i) Use of bark-free wood chips and other wood waste as a raw material input for the fibreboard making industries.

ii) Particleboard manufacturing using sawdust and wood chips along with low-cost, nonconventional wastes like shredded currency wastes and paper mill wastes

iii) Use of wood and bark chips as coloured mulch for gardens, highway verges, and agriculture.

iv) Use of Sawdust and wood shavings for animal bedding.

\section{Conclusion}

The problem of managing the solid wastes has acquired alarming dimensions especially over the last two decades. In the early days, waste management was hardly considered as an issue of concern as the waste could be easily disposed off in a safe manner within the premises where it is generated. With time, due to changes in our lifestyle coupled with urbanization and industrialization, the quantity and the characteristics of the wastes have changed dramatically leading to the present situation and it plays a major role in the increased threats to the environment. Environmental degradation is one of the most urgent environmental issues which require our careful attention. Some environments may not recover at all depending upon the extent of damage. The plants and animals that inhabited these places will be lost forever. We must consider the long-term effects of our developmental activities, so as to considerably reduce any future impacts on the environment. Since there is no single solution, the proposed recycling 


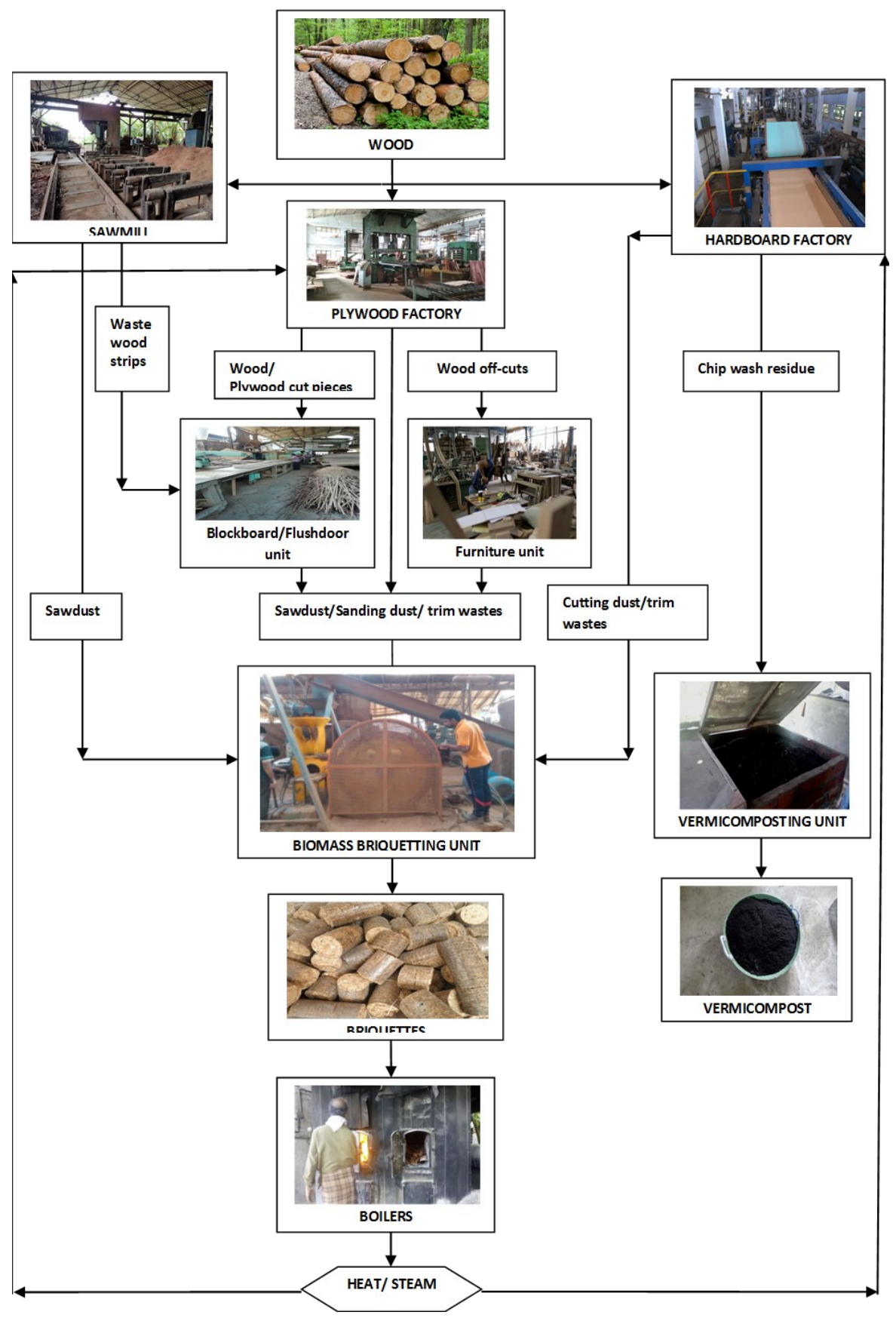

Figure 5. Material flow of wood and wood wastes in a large wood-based industrial complex. 
methods can be used to adopt an integrated solid waste management system based on our local needs and socioeconomic settings in order to ensure the acceptability of the system and the environmental sustainability. In addition to sound planning, public awareness and community participation, there is an urgent need to support the industries in adopting latest technologies for managing the huge quantity of wastes generated from their processing units in order to prevent the contributions from the sector to the environmental degradations in the future.

\section{Acknowledgement}

The author wishes to express his sincere thanks to Shri. P.K. Mayan Mohamed, Managing Director of The Western India Plywoods Ltd, Kannur, Kerala for his support and constant encouragement in carrying out the wood waste management related projects and also for his permission to publish this article.

\section{References}

Adhikari, B.K., Barrington, S., Martinez, J. and King, S. (2008). Characterization of food wastes and bulking agents for composting, Waste Management, 28: 795-804

Botkin, D.B. and Keller, E.A. (2000). Environmental Science-Earth as a Living Planet. III Ed JohnWiley \& Sons. New York. pp. 572-593.

Gupta, P.K., Jha, A.K., Koul, S., Sharma, P., Pradhan, V., Gupta, V., Sharma, C. and Singh, N. (2007). Methane and nitrous oxide Emission from bovine Manure. Management Practices in India. Journal of Environmental Pollution, 146(1): $219-224$

Higa, T. and Chinen, N. (1998). EM treatment of odour, wastewater and environmental problems. Okinawa, Japan: University of Ryukus, College of Agriculture.

Kansal, A. (2002). Solid waste management strategies for India. Indian Journal of Environmental Protection. 22(4): 444-448.

Karunanithy, C., Wang, Y., Uthukumarappan, K., Pugalendhi, S. (2012). Physicochemical characterization of briquettes made from different feed-stocks, Biotechnology Research International, 1-12. https:// doi.org/10.1155/2012/165202.

Kumar, V., Singh, J., Nadeem, M., Kumar, P. and Pathak, V.V. (2018). Experimental and kinetics studies for biogas production using water hyacinth (Eichhornia crassipes [Mart.] Solms) and sugar mill effluent. Waste and Biomass Valorization, 1-11. https:/ / doi.org/10.1007/s12649-018-0412-9

MoUD. (2000).Municipal Solid Waste (Management and Handling) Rules, Ministry of Environment and Forests, Government of India, issued on 25 September.

Nagavallemma, K.P., Wani, S.P., Lacroix, S., Padmaja, V.V., Vineela, C., Babu Rao, M. and Sahrawat, K.L. (2004). Vermicomposting: Recycling wastes into valuable organic fertilizer. Global Theme on Agrecosystems Report no. 8. Patancheru 502 324, Andhra Pradesh, India: International Crops Research Institute for the Semi-Arid Tropics. pp. 20.

Oluchukwu, A.C, Nebechukwu, A.G and Egbuna, S.O.(2018). Enrichment of nutritional contents of sawdust by composting with other nitrogen rich agro-wastes for bio-fertilizer synthesis. Journal of Chemical Technology and Metallurgy, 53(3): 430436

Rajput,R., Prasad,G. and Chopra, A.K. (2009). Scenario of solid waste management in present Indian context. Caspian Journal of Environmental. Science, 7(1): 45-53

Ramachandra T.V. and Bachamanda, S. (2007). Environnemental audit of municipal solid waste management. International Journal of Environmental Technology and Management, 7(3/4): 369-391 
Sharholy, M., Ahmad, K., Mahmood, G. and Trivedi, R.C. (2008). Municipal solid waste management in Indian cities - A review. Journal of Waste Management, 28(2): 459- 467

Sreenivasan, E. (2013). Evaluation of Effective Microorganisms Technology in industrial wood waste management. International Journal of Advanced Engineering ETechnology, 4(3): 21-22

Sreenivasan, E. (2013). Bioconversion of industrial wood wastes into vermicompost by utilizing African night crawlers (Eudrilus eugeniae). International Journal of Advanced Engineering ETechnology, 4(3): 19-20

Sreenivasan, E., Anish, M.C., Mobin, K.M. and Niyas, P. (2017). Effect of vermicompost produced from industrial wood waste on vegetables under field conditions. International Journal of Farm Sciences, 7(3): 11-15

Srivastava, P.K., Kushreshtha, K., Mohanty, C.S., Pushpangadan, P. and Singh, A. (2005): Stakeholder-based SWOT analysis for successful municipal solid waste management in Lucknow, India. Journal of Waste Management, 25 (5): 531-537

Surabhi, C., Anish, M.C., Mobin, K.M., Niyas, P. and Sreenivasan, E. (2017): A Feasibility Study on Composite Bricks from Sawdust and Boiler Ash Using Cement as A Binder. Trends in Biosciences, 10(3): 1049-1052

Tuomela, M., Vikman, M., Hatakka, A., and Itavaara, M. (2000). Biodegradation of lignin in a compost environment: a review, Bioresource Technology, 72: 169-183

$\star \star \star \star \star *$

Cite this chapter as: Sreenivasan, E. (2020). Solid waste management and its role in mitigating environmental degradation with special reference to recycling of wood wastes. In: Environmental Degradation: Causes and Remediation Strategies, Volume 1, Eds. Kumar, V., Singh, J. and Kumar, P., pp. 166-182, https://doi.org/10.26832/aesa-2020-edcrs-012 